\title{
Üniversite Öğrencilerinin Aile Aidiyeti ve Özgeci Davranışlart Arasındaki İlişkinin İncelenmesi: Konya İli Örneği
}

\author{
Investigation Of Relationship Between Family Belonging And Alturistic Behaviors Of \\ University Students: The Case Of Konya Province \\ Sezen Gizem ÖZDEMIR* \\ Serap $D A S B B S^{* *}$ \\ Nur Feyzal KESEN***
}

$\ddot{O} Z$

Bu araştırmada, üniversite öğrencilerinin aile aidiyeti ve özgeci davranışlarına çeşitli değişkenlerin etkisinin incelenmesi ve aile aidiyetiyle özgeci davranışları arasındaki ilişkinin ortaya koyulması amaçlanmıştır. Tarama modelindeki bu araştırma, Konya ilinde çeşitli üniversitelerde eğitimine devam etmekte olan ve gönüllü katılım sağlayan 987 üniversite ögrencisiyle gerçekleştirilmiştir. Veriler Katılımcı Bilgi Formu, Aile Aidiyeti Ölçeği ve Özgecilik Ölçeği ile toplanmıştır. Verilerin analizi SPSS Statistic 20 programı kullanılarak yapılmıştır. Verilerin normal dağılıma uygun olduğu görülmüş ve Independent-Samples T Testi, One-Way ANOVA testleri ve Pearson Kolerasyon testleri yapılmiştır. Üniversite öğrencilerinin aile aidiyeti ile özgeci davranışlar arasında pozitif yönlü anlamlı bir ilişki bulunmuştur. Ayrıca, aileyle düzenli zaman geçirme sıklı̆̆l, ailelerinde yaşanan problemlerde katılımcıların takındıkları tutumlarl, aile-akraba ilişkileri, yardım isteyebilecekleri arkadaş sayıları, yaşamlarının çoğunda hissettikleri duyguları, ailelerinin duygularını anlama durumu, ailelerinin yanında ağlayabilme durumu ve ailelerinin kendilerini başkalarıla kıyaslama durumu bağımsız değişkenleri ile aile aidiyeti ve özgeci davranışları arasında anlamlı bir farklılık bulunmuştur. Örneğin, aile aidiyeti yüksek olan ögrenciler, aileleri tarafından kıyaslanmadı̆̆ını ve ailelerinin yanında ăglayabildiklerini belirtmiştir. 7 ve üstü sayıda arkadaşından yardım isteyebileceğini belirten ögrenciler daha yardımseverdir. Ailede yaşanan probleme uyumlu tutumda bulunan ögrencilerin aidiyeti ve sorumluluk davranışları yüksektir.

ANAHTAR KELIMELER

Prososyal, Aile Aidiyeti, Özgeci Davranış, Öğrenci.

\begin{abstract}
In this study, it is aimed to investigate the effect of various variables on family belonging and altruistic behaviors of university students and to reveal the relationship between family belonging and altruistic behaviors. This survey model was conducted with 987 university students who are continuing their education at various universities in Konya province and who are participating voluntarily. The data were collected by the participatory fact sheet, the family belonging scale and the altruism scale. The analysis of the data was done using The SPSS Statistic 20 program. The data was found to be suitable for normal distribution and The Independent-Samples T Test, One-Way ANOVA tests and Pearson Choleration tests were conducted. A positive correlation was found between family belonging and altruistic behaviors of university students. Also, a significant difference was found between family belonging and altruistic behavior, with independent variables such as frequency of regular family time, attitudes of participants in their family problems, family-relative relationships, number of friends they could ask for help, feelings they felt most of their lives, understanding their family's feelings, crying next to their family, and comparing themselves with others. For example, the students with high family belonging stated that they were not compared by their families and that they could cry with their families. Students who are willing to ask for help from 7 or more friends are more helpful. Students who are in harmony with the problem experienced in the family have high belongingness and responsibility behaviors.
\end{abstract}

\section{KEYWORDS}

Prosocial, Family Belonging, Alturistic Behavior, Student

\begin{tabular}{|c|l|c|}
\hline \multicolumn{2}{|c|}{ Makale Geliş Tarihi / Submission Date } & \multicolumn{1}{c|}{ Makale Kabul Tarihi / Date of Acceptance } \\
18.09.2019
\end{tabular}

\footnotetext{
* Doktora Öğrencisi, Selçuk Üniversitesi, Sağlık Bilimleri Enstitüsü, Sosyal Hizmet Anabilim Dalı e-posta: gizemmm0942@ gmail.com, ORCID: 0000-0001-9381-0499

${ }^{* *}$ Doç. Dr. Öğr. Üyesi, Selçuk Üniversitesi, Sağlık Bilimleri Fakültesi, Sosyal Hizmet Anabilim Dalı e-posta: serapdasbas@ selcuk.edu.tr, ORCID: 0000-0003-0969-6393

**** Doç.Dr. Öğr. Üyesi, Selçuk Üniversitesi, Sağlık Bilimleri Fakültesi, Sosyal Hizmet Anabilim Dalı e-posta: nfkesen@ selcuk.edu.tr, ORCID: 0000-0002-6455-0293
} 


\section{GİRIŞ}

Aile, doğumundan ölümüne kadar bireyin ihtiyaçlarının karşılanması, toplumsal değer ve yargıların aktarılması, insani öğretilerin edinilmesi ve bireylerin sosyalleşmesi açısından önemli bir konuma sahiptir. Bu önemle birlikte, aile birliğinin korunması ve sürdürülmesinde aile üyelerinin birbirlerine yönelik takındıkları duygu, tutum ve davranışlar oldukça etkilidir. Yapılan davranışların, olumlu sosyal (prososyal) davranışları içermesi aile üyelerinin birbiriyle olan ilişkilerine katkı sağlayabilmektedir.

Bireyin, kendi isteği ve arzusuyla diğer birey veya bireylerin iyilik hallerine katk1 sağlamaya yönelik yaptığı davranışlar prososyal davranış olarak nitelendirilebilir (Görgülü ve ark 2018, Oktar 2018). Üyesi olduğu topluluğa aidiyet duymasına ve bu aidiyet duygusunun sürdürülmesini sağlayan prososyal davranışları nezaket, özgecilik, vicdan, erdem gibi tutumlar tetiklemektedir (Altıntaş ve Bıçakçı 2017, Öcal ve Sarnıç 2017, Akcay 2018).

Prososyal davranışları etkileyen olgulardan olan aidiyete ilişkin tanımlamalar, aitlik, mensubiyetlik kavramlarıyla veya bireyin içinde bulunduğu grup veya mekân ile birbirini karşılıklı olarak kabul etme ilişkisi şeklinde özetlenebilir (Çivitçi 2014, Mavili ve ark 2014, Güneş 2018, Saki 2018). Aidiyet, Maslow’un ihtiyaçlar hiyerarşisine göre fizyolojik ve güvenlik ihtiyacından hemen sonra gelmektedir. Bu ihtiyaç yalnızca duygu olarak değil, bireyin çevresiyle birlikte var olmayı ve deneyimlerini de kapsamaktadır (Mavili ve ark 2014, Saki 2018). Anlamlılık ihtiyacının giderilmesine yardımcı olan aidiyetin gerçekleşmesi için bireyin, aile gibi bazı objelere ihtiyacı vardır (Tarhan 2011). Birey aidiyet duyduğunda, içerisinde bulunduğu grubun yararı için özgeci davranışlar sergilemeye eğilimli olmaktadır (Çivitçi 2014).

Literatürde özgecilik ve özgeci davranış kavramları hakkındaki yorumlamalar, karşı1ık beklenmeksizin bir diğerine yapılan iyilikler olarak özetlenebilir (Ümmet 2012, Avc1 ve ark 2013, Kasapoğlu 2013, Harputlu 2015, Yeşilkayalı 2015, Akar 2016, Kılıç 2018). Egoizm (bencillik) kavramının tersi olarak düşünebilen özgecilik ve özgeci davranışlar, bilinçli ve istekli bir şekilde yardımsever olmayı, fedakârlı̆̆ı, empatiyi, sosyal sorumluluğu içermektedir (Ümmet 2012, Avc1 ve ark 2013, Kılıç 2018). Ussal vicdanı ve içsel doyumu sağlayan, çevreye uyum sağlamada ve sosyalleşmede etkili rol oynayan özgeci davranışları, bireyler genellikle akrabalık bağı olan diğer bireylere sergilemekte ve bu davranışları gördüğ̈ bireylere karşı sevgi ve aidiyet duyabilmektedir (Tarhan 2011, Harputlu 2015, Yeşilkayalı 2015, Kılıç 2018).

Bireyin sosyal öğrenme gerçekleştirmesi hususunda aile, aktif bir rol oynamaktadır. Birey, ailesinin gerçekleştirdiği bir davranış kalıbını gördüğünde, bu davranış zamanla öğrenilerek benimsenmesine neden olmaktadır (Çiftçi 1991, Dönmezler 1999, Kılıçarslan 2010, Kağıtçıbaş1 2013).

Her aile üyesinin, yapabilme potansiyellerine göre verilen sorumluluklarını yerine getirdiklerinde aile üyeleri -bilhassa öğrenme sürecindeki çocuklar- aile içi dayanışma becerisi kazanır (Saki 2018). Bu kazanımla üyeler, içerisinde bulundukları ailelerine aidiyet duygusu hissederken, bencil düşünce tarzını bırakarak özgeci davranışlar sergilemeye başlayabilir. Bu düşünceyle ilişkili olarak Alptekin (2011) çalışmasında aileye bağlılığı yüksek olan bireylerin aileleriyle karşılıklı dayanışma ve destek içerisinde olduklarını ifade ederken, Dönmezler (1999) ise koşulsuz sevgi ile olumlu davranışların gelişmesini sağladığını belirtmiştir. Bu bağlamda yapılan çalışmada aile aidiyeti ile özgeci davranışların ilişkisinin incelenmesi amaçlanmıştır. $\mathrm{Bu}$ amaca yönelik olarak çalışmanın yanıt aradığı sorular aşağıda sıralanmıştır.

1. Üniversite öğrencilerinin aile aidiyeti ve özgeci davranışları ile çeşitli değişkenler arasında anlamlı bir farkl11ık var midır?

2. Üniversite öğrencilerinin aile aidiyeti ile özgeci davranışları arasında anlamlı bir ilişki var mıdır?

$\mathrm{Bu}$ amaç doğrultusunda yapılan araştırma:

$\checkmark$ Katılımcıların aile aidiyeti ve özgeci davranışları arasındaki ilişkinin belirlenmesi açısından katılımcllara,

$\checkmark \quad$ Aile veya bireye yönelik aidiyet ve özgeci davranış temalarındaki yapılacak çalışmalara kılavuz olması açısından araştırmacılara,

$\checkmark$ Literatürde aile aidiyeti ve özgeci davranışların ilişkisinin değerlendirilmesi ve bu ilişkiye etki edebilecek değişkenler belirlenmesine yönelik çalışmaların olmaması bakımından literatüre,

$\checkmark \quad$ Mezzo ölçekte aile ve gençlerle yapılan çalışma ve hizmetlerin verimliliği açısından ilgili alanlarda görev alan çalışanlara,

$\checkmark$ Araştırmalardan yola çıkarak sunulan makro ölçekteki hizmet ve politikaların planlanması ve sunulması açısından politikacılara; nihayetinde ise topluma katkı sağlayabilecek bir öneme sahiptir.

\section{GEREÇ VE YÖNTEM}

Üniversite öğrencilerinin aile aidiyetlerinin ve özgeci davranışlarının birbiriyle olan ilişkisini incelemek amacıyla tarama yöntemi kullanılmıştır. 


\subsection{Evren ve Örneklem}

Araştırma, Konya ilinde bulunan çeşitli üniversitelerde öğrenimine devam etmekte olan öğrenciler ile gerçekleştirilmiştir. Araştırmanın evrenini Konya ilinde öğrenim görmekte olan tüm üniversite öğrencileri oluştururken, örneklem grubu küme örnekleme yoluyla nu araştırmaya gönüllü olarak katılım sağlayan bireyler ile oluşturmuştur ( $\mathrm{n}=987)$.

\subsection{Veri Toplama Araçları}

Araştırmadaki veriler Katılımcı Bilgi Formu, Aile Aidiyeti Ölçeği ve Özgecilik Ölçeği ile toplanmıştır.

Katılımcı Bilgi Formu: Araştırmacılar tarafından hazırlanan formun içeriğinde sosyodemografik bilgileri, aile tipi ve ilişkileri, ebeveyn bilgileri, katılımcının genellikle hissettiği duyguları ve takındığı tutumları ile sosyal çevresiyle olan ilişkilerine yönelik 10 soru yer almaktadır.

Aile Aidiyeti Ölçeği (AÄ̈): Mavili ve arkadaşları (2014) tarafindan geliştirilen Aile Aidiyeti Ölçeği bireylerin aile aidiyetlerini ortaya koyma amacıyla kullanılmaktadır. Ölçek, aile aidiyeti ve aileye bağlılık konularıyla ilgili yapılan literatür taramasıyla elde edilen ölçekler incelenerek hazırlanmıştır. Toplam 17 maddeden oluşturulan ölçek, kendilik aidiyeti ve aile aidiyeti olmak üzere iki alt boyuta sahiptir. "tamamen katılıyorum (5), katılıyorum (4), kararsızım (3), katılmıyorum (2), tamamen katılmıyorum (1)" olmak üzere beşli likert tipinde hazırlanan ölçeğin 5, 7,9 ve 12. maddeleri olumsuz maddeler olup tersten hesaplanmaktadır. Ters çevirme işlemi tamamlandıktan sonra $1,3,4,6,7,10,11,12,13,14,15$ ve 17 . soruların toplamı kendilik aidiyeti alt boyutunu ölçerken 2, 5, 8, 9 ve 16. soruların toplamı aile aidiyeti alt boyutunu ölçmektedir. Alt boyutların toplamıysa aile aidiyeti toplam puanını vermektedir. Ölçekten alınacak en düşük puan 17 iken en yüksek puan 85 'tir. Puan arttıkça aile aidiyeti artmaktadır. Kendilik aidiyeti alt boyutu Cronbach Alpha 0,93, aile aidiyeti alt boyutu ise 0,82 olarak bulunmuştur (Mavili ve ark 2014). Bu çalışmada ise Cronbach Alpha güvenirlik katsayısı 0,74 olarak bulunmuştur.

Özgecilik Ölçeği: London ve Robert Bower (1968) tarafindan hazırlanan ölçek, özgeci davranışları belirlemede kullanılmaktadır (London ve Bower 1968). Uyarlama çalışması Cantez, Aşkın ve Akbaba (1991) tarafından Akbaba'nın Grupla Psikolojik Danışmanın Sosyal Psikolojik Bir Kavram Olan Özgecilik Üzerine Etkisi isimli doktora tezinde kullanılmak üzere hazırlanmıştır. 20 maddeden oluşan ölçek "çok az(1), az (2), orta(3), fazla (4), çok fazla(5)" şeklinde seçeneklendirilmiş beşli likert tipinde hazırlanmıştır. Ölçek, aile alt boyutu (1, 2, 3, 4 ve 5. maddeler), sosyal alt boyutu $(6,7,8,9$ ve 10.maddeler), yardımseverlik alt boyutu (11, $12,13,14$ ve 15 . maddeler) ve sorumluluk alt boyutu $(16,17,18,19$ ve 20 . maddeler) olmak üzere dört alt boyutuna sahiptir. Puanlar arttıkça özgeci davranışlar artmaktadır (Akbaba 1994). Bu çalışmadaysa Cronbach Alpha güvenirlik katsayısı 0,81 olarak bulunmuştur.

\subsection{Uygulama}

Araştırma, 2017 yılında Konya'daki çeşitli üniversitelerde eğitimine devam eden öğrencilerle sınıf ortamında gerçekleştirilmiştir. Gönüllü olarak araştırmaya katılım sağlamak isteyen üniversite öğrencilerine Katılımcı Bilgi Formu, Aile Aidiyeti Ölçeği ve Özgecilik Ölçeği verilerek doldurulması istenmiştir. Veri toplama araçlarının katılımcılar tarafindan doldurulması yaklaşık 15 dakika sürmüştür.

\subsection{Değerlendirme}

Toplanan veriler IBM SPSS Statistic 20 programı ile değerlendirilmiştir. Aile Aidiyeti Ölçeği ve Özgecilik Ölçeği puanlarının normal dağılım gösterip göstermediğine bakılmıştır. Ölçeklerdeki tüm puanlarının normal dağ 11 lı göstermesi üzerine verilerin analizinde parametrik testlerden Independent-Samples T Test ve OneWay ANOVA testleri uygulanmıştır. Ayrıca aile aidiyeti ve özgecilik ölçeklerinin birbiriyle olan ilişkisinin incelenmesinde Pearson Kolerasyon analizi uygulanmıştır. İstatistikî anlamlandırmada \%95 güven aralığı baz alınmıştır.

\subsection{Etik Yönü}

Araştırma öncesinde üniversite öğrencileri çalışma hakkında bilgilendirilerek gönüllü onam alınmıştır. Araştırmada katılımcıların onurunu zedeleyecek herhangi bir soru sorulmamıştır.

\section{BULGULAR}

Araştırmaya 1005 üniversite öğrencisi katılım sağlamış, ancak daha sonra hatalı veriler çıkartılarak 987 katılımcı değerlendirmeye dâhil edilmiştir. Katılımcıların genel yapısına ilişkin bilgiler Tablo 1'de gösterilmiştir. 
Tablo 1 Örneklem Grubunun Genel Yapısına İlişkin Frekans ve Yüzde Değerleri

\begin{tabular}{|c|c|c|c|c|}
\hline \multicolumn{2}{|l|}{ Demografik Bilgiler } & \multirow{2}{*}{$\begin{array}{l}\mathbf{N} \\
547\end{array}$} & \multirow{2}{*}{$\begin{array}{l}\text { Yüzde } \\
55,4\end{array}$} & \multirow{2}{*}{\begin{tabular}{|l|} 
Toplam \\
987
\end{tabular}} \\
\hline Cinsiyet & Erkek & & & \\
\hline & Kadın & 440 & 44,6 & \\
\hline \multirow[t]{3}{*}{ Aile ile Düzenli Zaman } & Çoğunlukla & 541 & 54,9 & 985 \\
\hline & Ara Sira & 407 & 41,3 & \\
\hline & Hiç & 37 & 3,8 & \\
\hline \multirow[t]{4}{*}{ Ailedeki Probleme Yönelik Tutum } & Suçlayıc1-İlgisiz & 122 & 12,4 & 987 \\
\hline & Sakinleştirici & 341 & 34,5 & \\
\hline & Ak1lc1 & 316 & 32,0 & \\
\hline & Uyumlu & 208 & 21,1 & \\
\hline \multirow[t]{4}{*}{ Aile Akraba İlişkileri } & Hiç Görüşmüyorlar & 28 & 2,8 & 985 \\
\hline & Orta (Ne İyi Ne Kötü) & 315 & 32,0 & \\
\hline & İyi & 400 & 40,6 & \\
\hline & Çok İyi & 242 & 24,6 & \\
\hline Yardım İsteyebileceğiniz Arkadaş & 0-3 Arkadaş & 349 & 35,4 & 986 \\
\hline \multirow[t]{2}{*}{ Sayıs1 } & 4-6 Arkadaş & 346 & 35,1 & \\
\hline & 7 ve üstü & 291 & 29,5 & \\
\hline Yaşamın Genelinde Hissedilen & Sevinç ve Mutluluk & 559 & 57,0 & 981 \\
\hline \multirow[t]{3}{*}{ Duygu } & Üzüntü & 103 & 10,5 & \\
\hline & Öfke & 93 & 9,5 & \\
\hline & Kaygı ve Korku & 226 & 23,0 & \\
\hline Duygularınızı Ailenizin Anlama & Evet & 761 & 77,4 & 983 \\
\hline Durumu & Hayır & 222 & 22,6 & \\
\hline \multirow[t]{2}{*}{ Aile Yanında Ağlama Durumu } & Evet & 455 & 46,3 & 983 \\
\hline & Hayır & 528 & 53,7 & \\
\hline Ailenin Başkalarıyla Kıyaslama & Evet & 249 & 25,3 & 986 \\
\hline \multirow[t]{2}{*}{ Durumu } & Hayır & 363 & 36,3 & \\
\hline & Bazen & 374 & 37,9 & \\
\hline
\end{tabular}

Tablo 1'de verildiği gibi ögrencilerin \%55,4'ü erkek, \%44,6'sı kadın olup, yaş ortalamas1 20'dir. Öğrencilerin \%54,9'u çoğunlukla aileleri ile düzenli vakit geçirdiklerini ifade etmişlerdir. İhtiyaç duyduğu zamanlarda yardım isteyebilecekleri arkadaşlarının sayısı sorulduğunda ise öğrencilerin \%35,4'ü 0-3 sayıda arkadaşından yardım isteyebileceğini ifade etmiştir. Yaşamının genelinde katılımcıların \%57,0'si sevinç ve mutluluk hissettiğini belirtmiştir. Öğrencilere ailenizin ifade ettiğiniz duygularınızı anlayıp anlamadığ 1 sorulduğunda \%77,4’ü anladığını bildirirken \%53,7'si ailelerinin yanında ağlayamadığını ifade etmiştir.

\subsection{Bağımsız Değişkenler ile Aile Aidiyeti Ölçeği ve Özgecilik Ölçeği Puanlarının İlişkisi}

Katılımcıların araştırma sorularına yönelik olarak belirlenen bağımsız değişkenler, aile aidiyeti ölçeği puanları ve özgecilik ölçeği puanlarıyla analiz edilerek tablolaştırılarak Tablo 2 ve Tablo 3 'de gösterimi yapılmıştır.

Cinsiyet değişkeni ile tüm aile aidiyeti ölçeği ve özgecilik ölçeği alt boyutları arasında istatistikî açıdan anlamlı bir fark bulunamamıştır.

Aile ile düzenli zaman geçirme durumu değişkeni sonuçlarından elde edilen bilgilere göre, aile ile düzenli zaman geçirme durumun aile aidiyeti ölçeğinin tüm puanlarıyla istatistikî açıdan yüksek düzeyde anlamlı olduğu saptanmıştır. Elde edilen verilere göre, ailesiyle çoğunlukla düzenli vakit geçiren bireylerin aile aidiyeti ölçeğinin tüm boyutlarında daha yüksek ortalamaya sahip olduğu bulunmuştur. Özgecilik ölçeği alt boyutu puanları ile aileyle düzenli zaman geçirme değişkeni değerlendirildiğinde aile, sosyallik ve yardımseverlik alt boyutlarında istatistikî açıdan anlamlılık görülürken, sorumluluk alt boyutunda anlamlılık saptanmamıştır. Ayrıca, özgecilik ölçeğinin aile, sosyallik ve yardımseverlik alt boyutlarında yüksek ortalamaya sahip olan grubun, ailesiyle çoğunlukla düzenli vakit geçiren katılımcı grubu olduğu görülmüştür.

Yardım ihtiyacı duyduğunuzda yardım isteyebileceğiniz arkadaş sayıları değişkeni aile aidiyeti ölçeğinin ve özgecilik ölçeğinin tüm alt boyutlarda istatistikî açıdan anlamlı bir farklılık vardır. Aile aidiyeti ölçeğinin kendilik alt boyutunda yardım isteyebileceği 7 ve üstü arkadaşı olduğunu belirten grubun yüksek ortalamaya sahip olduğu görülürken, 4-6 arkadaş cevabını veren grubun aile aidiyeti alt boyutu ve aile aidiyeti toplam puanında daha yüksek ortalamaya sahip olduğu bulunmuştur. Özgecilik ölçeği alt boyutlarında ise aile alt boyutunda 4-6 arkadaş cevabını veren grup yüksek ortalamaya sahip grubu oluştururken, diğer özgecilik ölçeği alt boyutlarında 7 ve üstü arkadaş cevabını veren grubun yüksek ortalamaya sahip olduğu görülmüştür. 
Tablo 2 Bazı Bağımsız Değişkenler Açısından Aile Aidiyeti Ölçeği ve Özgecilik Ölçeği Puanlarının ANOVA ve T Testi Analizi Sonuçları

\begin{tabular}{|c|c|c|c|c|c|c|c|c|}
\hline & & \multicolumn{3}{|c|}{ Aile Aidiyeti Ölçeği Alt Boyutları } & \multicolumn{4}{|c|}{ Özgecilik Ölçeği Alt Boyutları } \\
\hline \multicolumn{2}{|c|}{ Bağımsız Değişkenler } & Kendilik & Aile Aidiyeti & Toplam Puan & Aile & Sosyallik & Yardımseverlik & Sorumluluk \\
\hline \multirow[t]{2}{*}{ Cinsiyet } & Erkek & $48,08 \pm 6,31$ & $17,70 \pm 3,02$ & $65,78 \pm 8,13$ & $19,77 \pm 2,83$ & $15,44 \pm 4,57$ & $19,72 \pm 3,29$ & $18,45 \pm 3,38$ \\
\hline & Kadın & $48,66 \pm 5,550$ & $17,72 \pm 2,77$ & $66,39 \pm 7,31$ & $19,95 \pm 2,56$ & $15,14 \pm 4,77$ & $19,91 \pm 2,67$ & $18,23 \pm 3,06$ \\
\hline t değeri & & $-1,528$ &,- 133 & $-1,225$ & $-1,046$ & 1,005 &,- 971 & 1,062 \\
\hline p değeri & &, 127 & ,894 &, 221 & ,296 &, 315 & ,332 & ,288 \\
\hline \multirow{3}{*}{$\begin{array}{l}\text { Aile ile Düzenli } \\
\text { Zaman }\end{array}$} & Çoğunlukla & $49,95 \pm 5,06$ & $18,21 \pm 2,77$ & $68,16 \pm 6,70$ & $20,52 \pm 2,38$ & $15,57 \pm 4,57$ & $20,53 \pm 2,70$ & $18,44 \pm 3,21$ \\
\hline & Ara Sira & $46,71 \pm 5,93$ & $17,16 \pm 2,89$ & $63,87 \pm 7,60$ & $19,17 \pm 2,70$ & $15,13 \pm 4,64$ & $19,08 \pm 2,93$ & $18,28 \pm 3,22$ \\
\hline & Hiç & $42,75 \pm 10,04$ & $16,45 \pm 3,71$ & $59,21 \pm 12,77$ & $17,70 \pm 4,28$ & $13,13 \pm 5,51$ & $17,10 \pm 4,75$ & $17,94 \pm 3,89$ \\
\hline F değeri & & 56,101 & 19,214 & 55,544 & 43,846 & 5,220 & 45,775 & ,612 \\
\hline p değeri & & ,000 & ,000 &, 000 & ,000 & ,006 &, 000 &, 542 \\
\hline \multirow{4}{*}{$\begin{array}{l}\text { Ailedeki } \\
\text { Probleme } \\
\text { Yönelik } \\
\text { Tutum }\end{array}$} & Suçlayıcı-İlgisiz & $45,00 \pm 7,19$ & $16,46 \pm 2,87$ & $61,47 \pm 8,85$ & $18,39 \pm 3,09$ & $14,09 \pm 5,13$ & $18,44 \pm 3,60$ & $17,77 \pm 3,31$ \\
\hline & Sakinleştirici & $48,98 \pm 6,22$ & $17,87 \pm 2,91$ & $66,86 \pm 7,94$ & $20,13 \pm 2,76$ & $15,29 \pm 4,62$ & $20,10 \pm 3,08$ & $18,33 \pm 3,17$ \\
\hline & Akılc1 & $48,16 \pm 5,62$ & $17,79 \pm 2,92$ & $65,96 \pm 7,34$ & $19,83 \pm 2,54$ & $15,74 \pm 4,57$ & $19,73 \pm 2,96$ & $18,30 \pm 3,21$ \\
\hline & Uyumlu & $49,51 \pm 4,53$ & $18,03 \pm 2,75$ & $67,55 \pm 6,41$ & $20,30 \pm 2,37$ & $15,40 \pm 4,48$ & $20,24 \pm 2,37$ & $18,82 \pm 3,31$ \\
\hline \multicolumn{2}{|l|}{ F değeri } & 17,488 & 8,953 & 18,913 & 15,481 & 3,727 & 11,180 & 2,766 \\
\hline \multicolumn{2}{|l|}{ p değeri } & ,000 & ,000 & ,000 &, 000 &, 011 &, 000 &, 041 \\
\hline \multirow{4}{*}{$\begin{array}{l}\text { Aile ile Akraba } \\
\text { İlişkisi }\end{array}$} & Hiç & $42,75 \pm 8,50$ & $16,89 \pm 3,64$ & $59,64 \pm 11,11$ & $17,96 \pm 3,92$ & $11,71 \pm 5,05$ & $17,35 \pm 4,23$ & $18,00 \pm 3,74$ \\
\hline & Ne İyi Ne Kötü & $46,85 \pm 6,38$ & $17,28 \pm 2,94$ & $64,13 \pm 8,17$ & $19,13 \pm 2,94$ & $14,86 \pm 4,58$ & $19,27 \pm 3,07$ & $18,09 \pm 3,19$ \\
\hline & İyi & $48,85 \pm 5,35$ & $17,82 \pm 2,83$ & $66,67 \pm 7,11$ & $20,08 \pm 2,48$ & $15,24 \pm 4,53$ & $19,95 \pm 2,82$ & $18,21 \pm 2,97$ \\
\hline & Çok İyi & $50,16 \pm 5,18$ & $18,17 \pm 2,84$ & $68,33 \pm 6,78$ & $20,66 \pm 2,26$ & $16,40 \pm 4,64$ & $20,55 \pm 2,88$ & $18,99 \pm 3,59$ \\
\hline \multicolumn{2}{|l|}{ F değeri } & $\mathbf{2 4 , 8 3 7}$ & 5,286 & 21,895 & 21,182 & 11,314 & 15,222 & 4,200 \\
\hline \multicolumn{2}{|l|}{ p değeri } &, 000 & ,001 & ,000 & ,000 & ,000 &, 000 & ,006 \\
\hline
\end{tabular}

Selçuk Üniversitesi Sosyal Bilimler Meslek Yüksekokulu Dergisi, Yıl: 2020 Cilt: 23 Sayı:1 
Tablo 3 Bazı Bağımsız Değişkenler Açısından Aile Aidiyeti Ölçeği ve Özgecilik Ölçeği Puanlarının ANOVA ve T Testi Analizi Sonuçları

\begin{tabular}{|c|c|c|c|c|c|c|c|c|}
\hline & & \multicolumn{3}{|c|}{ Aile Aidiyeti Ölçeği Alt Boyutları } & \multicolumn{4}{|c|}{ Özgecilik Ölçeği Alt Boyutları } \\
\hline \multicolumn{2}{|c|}{ Bağımsız Değişkenler } & Kendilik & Aile Aidiyeti & Toplam Puan & Aile & Sosyallik & Yardımseverlik & Sorumluluk \\
\hline Yardım & 0-3 Arkadaş & $47,52 \pm 6,16$ & $17,36 \pm 2,89$ & $64,88 \pm 8,06$ & $19,44 \pm 2,88$ & $14,49 \pm 4,68$ & $19,41 \pm 3,01$ & $17,97 \pm 3,24$ \\
\hline İsteyebileceğiniz & 4-6 Arkadaş & $48,75 \pm 5,77$ & $18,00 \pm 2,80$ & $66,76 \pm 7,36$ & $20,12 \pm 2,63$ & $15,46 \pm 4,51$ & $19,98 \pm 3,00$ & $18,34 \pm 3,07$ \\
\hline Arkadaş Sayısı & 7 ve üstü & $48,83 \pm 5,97$ & $17,78 \pm 3,03$ & $66,62 \pm 7,77$ & $20,04 \pm 2,56$ & $16,09 \pm 4,67$ & $20,07 \pm 3,04$ & $18,84 \pm 3,37$ \\
\hline F değeri & & 5,132 & 4,434 & 6,240 & 6,375 & 9,856 & 4,698 & 5,795 \\
\hline p değeri & & ,006 &, 012 &, 002 & ,002 &, 000 & ,009 & ,003 \\
\hline Yaşamın & Sevinç-Mutluluk & $49,29 \pm 5,55$ & $18,12 \pm 2,86$ & $67,42 \pm 7,23$ & $20,30 \pm 2,47$ & $15,92 \pm 4,57$ & $20,20 \pm 2,97$ & $18,76 \pm 3,08$ \\
\hline Genelinde & Üzüntü & $46,11 \pm 7,23$ & $16,76 \pm 3,01$ & $62,88 \pm 9,33$ & $18,72 \pm 3,16$ & $13,87 \pm 4,90$ & $19,17 \pm 3,31$ & $18,16 \pm 3,45$ \\
\hline \multirow[t]{2}{*}{ Hissedilen Duygu } & Öfke & $46,32 \pm 6,42$ & $17,25 \pm 2,97$ & $63,58 \pm 8,08$ & $19,13 \pm 2,96$ & $15,06 \pm 4,70$ & $18,96 \pm 3,25$ & $17,77 \pm 2,84$ \\
\hline & Kayg1-Korku & $47,91 \pm 5,66$ & $17,27 \pm 2,74$ & $65,19 \pm 7,26$ & $19,61 \pm 2,73$ & $14,47 \pm 4,46$ & $19,46 \pm 2,77$ & $17,69 \pm 3,42$ \\
\hline F değeri & & 13,961 & 10,104 & 16,388 & 14,248 & 9,281 & 8,257 & 7,549 \\
\hline p değeri & &, 000 &, 000 &, 000 & ,000 & ,000 &, 000 &, 000 \\
\hline Duygularınızın & Evet & $49,51 \pm 5,13$ & $18,12 \pm 2,77$ & $67,63 \pm 6,79$ & $20,39 \pm 2,32$ & $15,65 \pm 4,62$ & $20,31 \pm 2,78$ & $18,54 \pm 3,22$ \\
\hline Anlaşılma D. & Hayır & $44,27 \pm 6,91$ & $16,31 \pm 2,98$ & $60,58 \pm 8,48$ & $18,04 \pm 3,19$ & $14,09 \pm 4,61$ & $18,07 \pm 3,19$ & $17,73 \pm 3,25$ \\
\hline t değeri & & 10,476 & 8,422 & 11,358 & 10,200 & 4,435 & 10,166 & 3,273 \\
\hline p değeri & &, 000 &, 000 &, 000 &, 000 &, 000 &, 000 &, 001 \\
\hline Aile Yanında & Evet & $49,52 \pm 4,87$ & $18,23 \pm 2,73$ & $67,75 \pm 6,56$ & $20,42 \pm 2,36$ & $15,59 \pm 4,50$ & $20,20 \pm 2,61$ & $18,55 \pm 3,04$ \\
\hline Ăglayabilme & Hayır & $47,29 \pm 6,64$ & $17,25 \pm 2,99$ & $64,55 \pm 8,42$ & $19,35 \pm 2,90$ & $15,08 \pm 4,80$ & $19,45 \pm 3,30$ & $18,17 \pm 3,40$ \\
\hline t değeri & & 6,046 & 5,296 & 6,697 & 6,350 & 1,696 & 3,926 & 1,807 \\
\hline p değeri & &, 000 &, 000 &, 000 &, 000 & ,090 &, 000 &, 071 \\
\hline Ailenin & Evet & $46,57 \pm 6,77$ & $16,79 \pm 3,01$ & $63,37 \pm 8,65$ & $18,83 \pm 3,01$ & $15,05 \pm 4,63$ & $19,20 \pm 3,34$ & $18,42 \pm 3,42$ \\
\hline Başkalarıyla & Hayır & $49,43 \pm 5,79$ & $18,39 \pm 3,04$ & $67,82 \pm 7,56$ & $20,53 \pm 2,63$ & $15,47 \pm 4,68$ & $20,22 \pm 2,94$ & $18,58 \pm 3,28$ \\
\hline Kiyaslaması & Bazen & $48,44 \pm 5,33$ & $17,66 \pm 2,53$ & $66,11 \pm 6,83$ & $19,88 \pm 2,37$ & $15,33 \pm 4,67$ & $19,79 \pm 2,81$ & $18,09 \pm 3,06$ \\
\hline F değeri & & 17,402 & 23,196 & 25,365 & 30,869 & ,611 & 8,580 & 2,175 \\
\hline p değeri & &, 000 &, 000 & ,000 & ,000 & ,543 & ,000 &, 114 \\
\hline
\end{tabular}

Selçuk Üniversitesi Sosyal Bilimler Meslek Yüksekokulu Dergisi, Yıl: 2020 Cilt: 23 Sayı:1 
Yaşamın genelinde katılımcıların hissettikleri sevinç ve mutluluk duygusu değişkenine göre her iki ölçeğin tüm alt boyutlarında istatistikî olarak yüksek düzeyde anlamlı farklılık saptanmıştır.

Aileyle iletişim kurarken ifade edilen duyguları, ailenin anlama durumu değişkenine göre aile aidiyeti ölçeği ve özgecilik ölçeği alt boyutların tamamında istatistikî açıdan yüksek düzeyde anlamlı bir farklılık vardır. Alınan cevaplara bakıldığında ailelerinin ifade ettikleri duygularını anladıklarını belirten grubun diğer gruplara kıyasla her iki ölçeğin tüm alt boyutlarında daha yüksek puan ortalaması aldığı görülmüştür.

Ailenin yanında ağlayabilme durumu aile aidiyeti ölçeği alt boyutlarınca incelendiğinde istatistikî olarak yüksek düzeyde anlamlı bir fark olduğu görülmüsştür. Ağlayabilme değişkeni ile özgecilik ölçeği ele alındığında ise aile alt boyutu ve yardımseverlik alt boyutunda istatistikî açıdan yüksek düzeyde anlamlı bir fark görülürken, sosyallik ve sorumluluk alt boyutlarında istatistikî anlamlılık bulunmamaktadır. Aile aidiyeti ölçeğinin kendilik aidiyeti alt boyutu, aile aidiyeti alt boyutu ve aile aidiyeti toplam puanı boyutu ile özgecilik ölçeğinin aile alt boyutu ve yardımseverlik alt boyutu ortalama puanlarında daha yüksek puan alan grup ailesinin yanında ağlayabildiğini belirten gruptur.

Ailenin sizi başkalarıyla kıyaslama durumuna göre yapılan aile aidiyeti ölçeği ve özgecilik ölçeği puanları analiz edilmiştir. Analiz sonuçlarına göre aile aidiyeti ölçeğinin tüm alt boyutlarında ve özgecilik ölçeğinin aile ve yardımseverlik alt boyutunda istatistikî açıdan yüksek düzeyde anlamlı bir fark bulunurken, özgecilik ölçeğinin sosyallik ve sorumluluk alt boyutlarında anlamlı bir fark bulunmamaktadır. Ailesinin kendisini başkalarıyla kıyaslamadığını bildiren grup aile aidiyeti ölçeğinin ve özgecilik ölçeğinin tüm alt boyutlarında daha yüksek puan ortalamasına sahiptir.

\subsection{Aile Aidiyeti Ölçeği ile Özgecilik Ölçeği Puanlarının Birbiriyle İliş̧kisi}

Katılımcıların aile aidiyeti ve aidiyet alt kategorileri ile özgecilik ve özgecilik alt kategorileri arasındaki ilişkilerine yönelik korelasyon sonuçları tablolaştırılmıştır (Tablo 4).

Tablo 4 Aile Aidiyeti Ölçeği ve Özgecilik Ölçeği Puanlarının Pearson Korelasyon Analizi Sonuçları

\begin{tabular}{|c|c|c|c|c|c|c|c|c|}
\hline & & $\mathbf{I}$ & II & III & IV & $\mathbf{V}$ & VI & VII \\
\hline \multirow{6}{*}{ 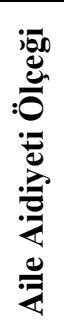 } & Kendilik & 1 & $\mathrm{R}=, 459$ & $\mathrm{R}=, 943$ & $\mathrm{R}=, 718$ & $\mathrm{R}=, 188$ & $\mathrm{R}=, 885$ & $\mathrm{R}=, 220$ \\
\hline & (I) & & $\mathrm{p}=, 000$ & $\mathrm{p}=, 000$ & $\mathrm{p}=, 000$ & $\mathrm{p}=, 000$ & $\mathrm{p}=, 000$ & $\mathrm{p}=, 000$ \\
\hline & Aile Aidiyeti & & 1 & $\mathrm{R}=, 729$ & $\mathrm{R}=, 687$ & $\mathrm{R}=, 170$ & $\mathrm{R}=, 418$ & $\mathrm{R}=, 210$ \\
\hline & (II) & & & $\mathrm{p}=, 000$ & $\mathrm{p}=, 000$ & $\mathrm{p}=, 000$ & $\mathrm{p}=, 000$ & $\mathrm{p}=, 000$ \\
\hline & Toplam Puan & & & 1 & $\mathrm{R}=, 811$ & $\mathrm{R}=, 209$ & $\mathrm{R}=, 839$ & $\mathrm{R}=, 248$ \\
\hline & (III) & & & & $\mathrm{p}=, 000$ & $\mathrm{p}=, 000$ & $\mathrm{p}=, 000$ & $\mathrm{p}=, 000$ \\
\hline \multirow{8}{*}{ 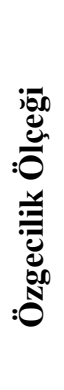 } & Aile & & & & 1 & $\mathrm{R}=, 168$ & $\mathrm{R}=, 524$ & $\mathrm{R}=, 196$ \\
\hline & (IV) & & & & & $\mathrm{p}=, 000$ & $\mathrm{p}=, 000$ & $\mathrm{p}=, 000$ \\
\hline & Sosyallik & & & & & 1 & $\mathrm{R}=, 177$ & $\mathrm{R}=, 314$ \\
\hline & (V) & & & & & & $\mathrm{p}=, 000$ & $\mathrm{p}=, 000$ \\
\hline & Yardımseverlik & & & & & & 1 & $\mathrm{R}=, 220$ \\
\hline & (VI) & & & & & & & $\mathrm{p}=, 000$ \\
\hline & Sorumluluk & & & & & & & 1 \\
\hline & (VII) & & & & & & & \\
\hline
\end{tabular}

Yapılan analizlere göre; aile aidiyeti ölçeğinin kendilik alt boyutu açısından ele alındığında özgecilik ölçeğinin aile alt boyutu $(\mathrm{R}=, 718)$ ve yardımseverlik alt boyutu $(\mathrm{R}=, 885)$ ile yüksek düzeyde pozitif yönde bir ilişki söz konusu iken, sosyallik alt boyutu $(R=, 188)$ ve sorumluluk alt boyutu $(R=, 220)$ ile düşük düzeyde pozitif yönde bir ilişki olduğu saptanmıştır.

Aile aidiyeti ölçeğinin aile aidiyeti alt boyutu açısından incelendiğinde özgecilik ölçeğinin aile alt boyutu $(\mathrm{R}=, 687)$ ve yardımseverlik alt boyutu $(\mathrm{R}=, 418)$ ile orta düzeyde pozitif yönde bir ilişkinin olduğu; sosyallik alt boyutu $(\mathrm{R}=, 170)$ ve sorumluluk alt boyutuyla $(\mathrm{R}=, 210)$ ise düşük düzeyde pozitif yönde bir ilişki olduğu belirlenmiştir.

Aile aidiyeti ölçeğinin toplam puanı açısından ele alındığında özgecilik ölçeğinin aile alt boyutu $(\mathrm{R}=, 811)$ ve yardımseverlik alt boyutu $(\mathrm{R}=, 839)$ ile yüksek düzeyde pozitif yönde bir ilişki bulunurken, sosyallik alt boyutu $(\mathrm{R}=, 209)$ ve sorumluluk alt boyutu $(\mathrm{R}=, 248)$ ile düşük düzeyde pozitif yönde bir ilişki söz konusudur. 


\section{TARTIȘMA}

Yapılan çalışmanın ana amacı aile aidiyeti ile özgeci davranışların ilişkisini incelemektir. Çalışmada ayrıca katılımcıların cinsiyet, aileyle düzenli zaman geçirme sıklığı, ailelerinde yaşanan problemlerde takındıkları tutumları, aile-akraba ilişkileri, yardım isteyebilecekleri arkadaş sayıları, yaşamlarının çoğunda hissettikleri duyguları, ailelerinin duygularını anlama durumu, ailelerinin yanında ağlayabilme durumu ve ailelerinin kendilerini başkalarıyla kıyaslama durumuna da bakılmıştır.

Araştırma verilerine bakıldığında aile aidiyeti puanları cinsiyet bakımından anlamlı farklılaşmamaktadır. Bulguların aksine literatürde yer verilen diğer çalışmalarda (Güneş 2018, Saki 2018) kadınların aile aidiyetlerinin erkeklerden daha yüksek olduğu görülmektedir. Cinsiyet açısından özgeci davranışların anlamlı farklılaşmadığı elde edilen diğer bulgulardandır. Literatürde benzer sonuçlara ulaşan çalışmaların (Kasapoğlu 2013, Yöntem 2013) olmasına karşın, cinsiyet açısından farklılaşmanın olduğu çalışmalarla (Sanadhya ve ark 2010, Carreon ve ark 2011, Ümmet 2012, Harputlu 2015, Yeşilkayalı 2015, Khalınbaylı 2018, Oktar 2018) da karşılaşılmıştır. Farklılaşmanın olduğu çalışmalarda kadınların daha özgeci davranışlara sahip olduğu görülmektedir.

Ailesiyle çoğunlukla düzenli zaman geçiren bireylerin diğerlerine kıyasla aile aidiyetinin ve özgeci davranışlarının yüksek olduğu söylenebilir. Çalışmaya paralel olarak literatürde aile içinde bireylerin birbirine bolca zaman ayırmasının ve samimi yaklaşımın aile üyeleri arasındaki aidiyeti arttırdığı görülmüştür (Çiftçi 1991, Kılıçarslan 2010). Ancak kaliteli ve düzenli vaktin geçirilememesiyle yaşanan iletişimin azlığ1, aile üyelerinin birbirinden uzaklaşmasına ve ilişkilerinin bozulmasına, aile içi paylaşımlarda isteksiz olmaya, aile güven ortamının zedelenmesine yol açtığı ve bazı bireylerinse sosyal medyaya yöneldiği alınan bilgiler arasındadır (Kağıtçıbaşı 1981, Dönmezler 1999, Karaca 2007, Yalçın ve Yalçın 2018).

Problemlerle karşılaştığında çözüm odaklı ve uyumlu tutumda bulunan katılımcı grubu, yüksek aile aidiyetine sahip olan ve daha özgeci davranış sergileyenlerden oluşmaktadır. Literatürde yaşanan problemlere yönelik tutumlara dair araştırmaların sınırlı olduğu görülmüş, yapılan araştırmayla benzer nitelikte olabilecek çalışmalardan problem çözme becerisi ve özgeciliğin ilişkisinin incelendiği bir çalışmada (Oktar 2018), özgeci davranışlarla problem çözme becerisinin pozitif yönlü bir ilişkisinin olduğundan bahsedilmektedir.

Katılımcıların ailelerinin akrabalarıyla olan ilişkilerinin çok iyi olduğunu belirten bireylerin, aile aidiyetinin yüksek olduğu ve daha özgeci davranışlarda bulunduğu söylenebilir. Aile akraba ilişkisine literatürde yakın olabilecek aile yapısı açısından incelendiğinde Güneş (2018)'in çalışmasında aile aidiyeti puanları geniş ve çekirdek aileye göre değişkenlik göstermezken, Saki (2018)'nin çalışmasında geniş ailedeki bireylerin, parçalanmış ailesi olan bireylere kıyasla yüksek aile aidiyetine sahip olduğu görülmektedir. Batı ülkelerinin aksine ülkemizde bireyler, sosyal, ekonomik vb problemlerin çözümünde akrabaları tarafindan desteklenebilmektedir (Ökten 2009, Özbay 2014). Ailelerine/akrabalarına maddi bağımlıkları olmasa bile hissettikleri sorumluluk ve zorunluluk gerekçesiyle, akrabalık ilişkilerinin kuşaklararasında öneminin korunduğu; bu nedenle bireylerin aidiyetinin yüksek olduğu ve özgeci davranışlar sergilemeye eğilimli olduğu görülmektedir (Kağıtçıbaşı 1981, Dönmezler 1999, Kağıtçıbaşı 2000, Ökten 2006).

Yardım isteyebileceği arkadaşlarının sayısı az olan katılımcıların ( 3 ve daha az), daha az aile aidiyeti ve özgeci davranış gösterme eğiliminde oldukları görülmüştür. Bu bulgulardan hareketle dışa dönük veya sosyal çevresi daha geniş olan bireylerin aile aidiyetinin ve özgeci davranışlarının daha yüksek olduğu düşünülebilir. Bu bağlamda araştırma literatürle (Ma 1993, Avcı ve ark 2013, Baskin ve ark 2014, Oktar 2018) paralellik göstermiştir.

Yaşamın genelinde sevinç ve mutluluk hisseden katılımcıların, aile aidiyetinin ve özgeci davranışlarının yüksek olduğu sonucuna varılmıştır. Bireyin yaşamının genelinde hissettiği sevinç ve mutluluk duygusu bireylerin psikolojik sağlamlığı ile yaşamlarından duydukları memnuniyet, doyum ve iyilik haliyle ilişkili olduğu düşünülebilir. Bu ilişki doğrultusunda araştırma sonuçları literatürdeki çalışmalarla (Ümmet 2012, Kasapoğlu 2013, Slaten ve Baskin 2013, Çivitçi 2014, Arslan 2015) benzer nitelik taşımaktadır.

Aile aidiyeti ve özgeci davranış puanları yüksek olan bireyler aileleri tarafindan anlaşıldığını ve ailelerinin yanında ağlayabildiklerini bildirmişlerdir. Aileyle olan iletişimde duyguların açılarak bireylerin anlaşılabilmesi ve ağlayabilmesi aile üyelerinin birbirlerine sundukları anlaşılabilirlik, güven ve ailenin yetiştirme yaklaşımıla ilgilidir (Roche ve ark 2003, Alptekin 2011, Ümmet 2012, Akdoğan ve Köksal 2014, King ve Boyd 2016). Literatürdeki diğer çalışmalara bakıldığında, çocuğun ailesinden beklediği en önemli ihtiyacının koşulsuz sevgi ve anlayış olduğu; etkin dinlemeyle iletişim sayesinde çocukların ailelerine duygularını açmasına ve problemlerine çözüm bulmasına yardımcı olduğu görülmektedir (Çiftçi 1991, Cüceloğlu 1997, Dönmezler 1999, Cüceloğlu 2001, Kılıçarslan 2010). Ailesinin kendisini anladığını hisseden 
birey, ailesi tarafından kabul edildiği düşüncesine ulaşarak ailesine sevgi ve aidiyeti artmaktadır (Çiftçi 1991, Dönmezler 1999, Çeçen 2008).

Ailesinin kendisini başkalarıyla kıyaslamadığını bildiren katılımcıların aile aidiyetinin tüm boyutlarında ve özgeciliğin ise aile ve yardımseverlik boyutunda anlamlı farklılık göstererek yüksek puan aldıkları gözlemlenmiştir. Kıyaslama bir duygusal istismar yöntemi olup, kıyaslandıkları bireylerle olan ilişkilerini olumsuz etkileyebilmekte ve bask1, stres ve kayg1 oluşturabilmektedir (Günalp 2007, Özgentürk 2014). Literatürde kıyaslamayla ilgili olarak bireyin mutsuzluluğuna, düşük benlik saygısına, yaşam doyumunda azalmaya, aşırı hırslı veya çekingen karaktere neden olduğundan ve bireyin ailesiyle olan ilişkilerini zedelediğinden bahsedilmektedir (Kandır ve Alpan 2008, Sözkesen ve Biçer 2018, Mamırova ve Yılmaz 2019).

Üniversite öğrencilerinin aile aidiyeti ile özgeci davranışları incelendiğinde, iki değişkenin birbirleriyle ilişkili olduğu görülmüştür. Yapılan analizlere göre bu ilişki, aile aidiyeti ve özgecilik arasında orta düzeyde pozitif yönlü bir artış yönündedir. Çalışmaya paralel olarak literatürde aile aidiyeti yüksek olan bireylerin destek ve dayanışma çerçevesinde birbirlerinin iyiliği için işbirliği, yardımlaşma, empati, hoşgörü gibi prososyal davranışları gerçekleştirme eğiliminde olduğu görülmüştür (Cüceloğlu 1997, Dönmezler 1999, Cüceloğlu 2001, Kandır ve Alpan 2008, Alptekin 2011).

Sonuç olarak, üniversite öğrencileriyle yapılan bu çalışmada aile aidiyeti ile özgeci davranışlar arasında bir ilişki bulunmuştur. Ayrıca, aileyle düzenli zaman geçirme sıklığı, ailelerinde yaşanan problemlerde katılımcıların takındıkları tutumları, aile-akraba ilişkileri, yardım isteyebilecekleri arkadaş sayıları, yaşamlarının çoğunda hissettikleri duyguları, ailelerinin duygularını anlama durumu, ailelerinin yanında ağlayabilme durumu ve ailelerinin kendilerini başkalarıyla kıyaslama durumunun aile aidiyetini ve özgeci davranışları üzerinde anlamlı bir farklılık yarattığı görülmüştür.

Yapılan çalışmayla temel işlevlerinden birinin sosyal öğrenme olduğu aile kuruma yönelik geliştirilen aidiyet ile bireylerin yine sosyal öğrenme yoluyla kazanabilecekleri prososyal davranışlardan olan özgeci davranışları arasında ilişki çeşitli değişkenlerle incelenmiştir. Aidiyet ve özgeciliği etkileyebileceği düşünülen kültür, toplumsal köken, değer ve yargıları içeren diğer etmenler üzerine fenomenoloji yaklaşımlı ileri araştırmalar önerilir. 


\section{KAYNAKÇA}

Akar A, 2016. Hemşirelerin Özgecilik Davranışlarının Transaksiyonel Analiz Ego Durumları Açısından İncelenmesi, Atatürk Üniversitesi, Erzurum.

Akbaba S, 1994. Grupla Psikolojik Danışmanın Sosyal Psikolojik Bir Kavram Olan Özgecilik Üzerine Etkisi, Atatürk Üniversitesi, Erzurum.

Akcay VH, 2018. Örgütlerde Prososyal Davranışlar, Sinizm ve Psikolojik Sermaye İlişsisi: Örgütle Özdeşleşmenin Moderatör Etkisi. Business and Economics Research Journal 9, 2, 381-93.

Akdoğan AA, Köksal O, 2014. Aidiyet Algısının Örgütsel Vatandaşlık Davranışı Üzerindeki Etkisinde Yöneticiye Güvenin Arac1lık Rolü Atatürk Üniversitesi Sosyal Bilimler Enstitüsü Dergisi, 18, 1, 25-43.

Alptekin D, 2011. Toplumsal Aidiyet ve Gençlik: Üniversite Gençliğinin Aidiyeti Üzerine Sosyoloik Bir Araştırma, Selçuk Üniversitesi, Konya.

Altıntaş TT, Bıçakçı MY, 2017. Erken Çocukluk Döneminde Prososyal Davranışlar. The Journal of Academic Social Science Studies, 57, 245-61.

Arslan G, 2015. Psikolojik İstismar, Psikolojik Sağlamlık, Sosyal Bağllık ve Aidıyet Duygusu Arasındaki İlişki. Mehmet Akif Ersoy Eğitim Fakültesi Dergisi, 36, 47-58.

Avcı D, Aydın D, Özbaşaran F, 2013. Hemşirelik Öğrencilerinde Empati-Özgecilik İlişkisi ve Özgeci Davranışın Bazı Değişkenler Açısından İncelenmesi. Balıkesir Sağlık Bilimleri Dergisi, 2, 2, 108-13.

Baskin TW, Quintana SM, Slaten CD, 2014. Family Belongingness Gang Friendships, and Psychological Distress in Adolescent Achievement. Journal of Counseling \& Development 92, 398-405.

Carreon D, Davidson P, Andersen R, Nakazono T, 2011. Altruism in Dental Students. Journal of Health Care for the Poor and Underserved 22, 1, 56-70.

Cüceloğlu D, 1997. İçimizdeki Çocuk, İstanbul, Remzi Kitabevi, p.

Cüceloğlu D, 2001. İyi Düşün Doğru Karar Ver İstanbul, Remzi Kitabevi, p.

Çeçen AR, 2008. Üniversite Öğrencilerinde Yaşam Doyumunu Yordamada Bireysel Bütünlük (Tutarll1ık) Duygusu, Aile Bütünlük Duygusu ve Benlik Saygısı. Eğitimde Kuram ve Uygulama, 4, 1.

Çiftçi O, 1991. Çocuğun Sosyalleşmesinde Ailenin Rolü. Aile ve Toplum Dergisi, 1, 2.

Çivitçi A, 2014. Üniversite Öğrencilerinde Olumlu Duygulanım ve Benlik Saygısı: Üniversite Doyumu ve Aidiyetinin Düzenleyici Rolü. Yükseköğretim Dergisi, 4, 2, 102-9.

Dönmezler İ, 1999. Ailede İletişim ve Etkileşim, İstanbul, Sistem Yayıncılık, p.

Görgülü R, Adiloğulları GE, Tosun ÖM, Adiloğulları İ, 2018. Prososyal ve Antisosyal Davranış ile Sporcu Kimliğinin Bazı Değişkenlere Göre İncelenmesi. Spor ve Performans Araştırmaları Dergisi, 9, 3, 147-61.

Günalp A, 2007. Farklı Anne Baba Tutumlarının Okul Öncesi Eğitim Çağındaki Çocukların Özgüven Duygusunun Gelişimine Etkisi (Aksaray İli Örneği), Selçuk Üniversitesi, Konya.

Güneş F, 2018. Genç Yetişkinlerde Güvengenlik Ve Utangaçlık: Aile Aidiyet Duygusunun Ve Duygu-Düzenlemede ÖzYeterlik Algısının Belirleyici Etkisi, Marmara Üniversitesi, İstanbul.

Harputlu İ, 2015. Dini Tutum ve Özgecilik İlişkisi (SDÜ Örneği), Süleyman Demirel Üniversitesi, Isparta.

Kağıtçıbaşı Ç, 1981. Çocuğun Değeri Türkiye'de Değerler ve Doğurganlık, İstanbul, Boğaziçi Üniversitesi, p.

Kağıtçıbaşı Ç, 2000. Kültürel Psikoloji Kültür Bağlamında İnsan ve Aile, İstanbul, Evrim Yayınevi, p.

Kağıtçıbaşı Ç, 2013. Günümüzde İnsan ve İnsanlar Sosyal Psikolojiye Giriş, İstanbul, Evrim Yayınevi, p.

Kandır A, Alpan Y, 2008. Okul Öncesi Dönemde Sosyal- Duygusal Gelişime Anne- Baba Davranışlarının Etkisi. Aile ve Toplum Dergisi, 4, 14.

Karaca M, 2007. Aileyi Tehdit Eden Yeni Bir Tehlike: Sanal İlişkiler e-Journal of New World Sciences Academy 2, 3.

Kasapoğlu F, 2013. Üniversite Öğrencilerinde İyilik Hali ile Özgecilik Arasındaki İlişkinin İncelenmesi, İnönü Üniversitesi, Malatya.

Khalınbaylı K, 2018. Üniversite Öğrencilerinde Özgecilik ve Mükemmeliyetçilik Anlayışı Arasındaki İlişkinin İncelenmesi, İstanbul Sabahattin Zaim Üniversitesi, İstanbul.

Kılıç Y, 2018. Kadınlarda Kariyer Hedeflerinin Yordayıcıları Olarak Aile Ve Kariyere Yönelík Tutum Özgecilik ve Dindarlık: Bir Model Test Etme Çalışması, Ondokuz Mayıs Üniversitesi, Samsun.

Kılıçarslan F, 2010. Çocuk ve Aile Sorunlarının Terapi ile Tedavisi, Ankara, Nobel Yayın Dağıtım, p.

King V, Boyd LM, 2016. Factors Associated With Perceptions of Family Belonging Among Adolescents. Journal of Marriage and Family, 78, 4, 1114-30.

London P, Bower KR, 1968. Altruism, Extraversion and Mental Illness. The Journal of Social Psychology, 76, 1, 19-30.

Ma HK, 1993. The Relation of Altruistic Orientation to Human Relationships and Situational Factors in Chinese Children. The Journal of Genetic Psychology: Research and Theory on Human Development 154, 1, 85-96.

Mamırova C, Yılmaz H, 2019. İtaatkârlar Daha mı Mutlu? "Pozitif Psikoloji Perspekttifinden Boyun Eğicilik". Manas Sosyal Araştırmalar Dergisi, 8,1 .

Mavili A, Kesen NF, Daşbaş S, 2014. Aile Aidiyeti Ölçeği: Bir Ölçek Geliştirme Çalışması. Sosyal Politika Çalışmaları Dergisi, 33, 29-45.

Oktar S, 2018. Üniversite Öğrencilerinin Özgecilik, Kişilik Özellikleri ve Sosyal Problem Çözme Becerileri Arasındaki İlişkinin İncelenmesi, Selçuk Üniversitesi, Konya. 
Öcal H, Sarnıç A, 2017. Dönüştürücü Liderliğin Prososyal Örgütsel Davranış Üzerindeki Etkileri ve İmalat Endüstrisinde Bir Araştırma. AKÜ İktisadi ve İdari Bilimler Fakültesi Dergisi, 19, 2, 107-25.

Ökten Ş, 2006. GAP Bölgesi’nin Sosyo-Kültürel ve Yapısal Özelliklerinin Aile Yapısına Etkileri. Aile ve Toplum Dergisi, 3.

Ökten Ş, 2009. Aşiret, Akrabalık ve Sosyal Dayanışma: Geleneksel Hayatı Yönetme Biçimi. Aile ve Toplum Dergisi, 5.

Özbay F, (2014). Akrabalık ve Komşuluk İlişkileri. Türkiye Aile Yapısı Araştırması İleri Analiz Raporu Ankara, TC Aile ve Sosyal Politikalar Bakanlığı ve İPSOS.

Özgentürk İ, 2014. Çocuk İstismarı ve İhmal. International Journal of Human Sciences, 11, 2.

Roche WP, Scheetz AP, Dane FC, Parish DC, O’Shea JT, 2003. Medical Students' Attitudes in a PBL Curriculum Trust, Altruism, and Cynicism. Academic Medicine, 78, 4.

Saki Ü, 2018. Üniversite Öğrencilerinin Aile Aidiyet Düzeylerinin Spor Ve Farklı Değişkenler Açısından İncelenmesi Atatürk Üniversitesi, Erzurum.

Sanadhya R, Sharma DK, Sushil CS, 2010. A Comparative Study of Altruism Among The Boys And Girls of Joint And Nuclear Families. Journal of Mental Health and Human Behavior, 15, 2, 88-90.

Slaten CD, Baskin TW, 2013. Examining the Impact of Peer and Family Belongingness on the Career Decision-making Difficulties of Young Adults. Journal of Career Assessment, 22, 1, 59-74.

Sözkesen ME, Biçer S, 2018. Instagram'da Sosyal Kıyaslama, Benlik Saygısı ve Yaşam Doyumu İlişkisi: Fırat Üniversitesi Üzerinde Bir İncelemesi. Akdeniz İletişim Dergisi, 29.

Tarhan N, 2011. Güzel İnsan Modeli, İstanbul, Timaş Yayınları, p.

Ümmet D, 2012. Üniversite Öğrencilerinde Özgecilik Davranışının Transaksiyonel Analiz Ego Durumu ve Yaşam Doyumu Bağlamında İncelenmesi, Marmara Üniversitesi, İstanbul.

Yalçın M, Yalçın M, 2018. Sosyal Medya Kullanımı ve Aile İçi İletişim İlişkisi: Üniversite Öğrencileri Üzerine Bir Araştırma. Uluslararası Sosyal Araştırmalar Dergisi, 11, 57.

Yeşilkayalı HD, 2015. Koruyucu Aile Bireylerini Sosyodemografik Özellikleri ile Empatik Becerileri ve Özgecilik Durumları Arasindaki İlişkinin İncelenmesi, Ankara Üniversitesi, Ankara.

Yöntem MK, 2013. Benlik Kurguları Ve Otantikliğin Özgecilik Üzerindeki Yordayıcı Gücünün İncelenmesi Gaziosmanpaşa Üniversitesi, Tokat. 